\title{
Cloud Computing: Pricing Model
}

\author{
Aferdita Ibrahimi, Ph.D. Student, \\ Faculty of Contemporary Sciences and Technologies \\ South East European University \\ Tetovo, Macedonia
}

\begin{abstract}
Cloud computing is the elemental aspect for online security of computing resources. It helps on-demand dividing of resources and cost between a major number of end users. It provides end users to process, manage, and store data so fast with reasonable prices. This is significant to know the causes of embarrassment between clients in relation to cloud computing services, particularly when it comes to a new price method. The price presents an important element, an indicator that often shows the quality of services, but on the other hand, the salesman with its offer on services has an impact directly on clients' decisions to use them. For both providers and users of cloud services, identifying the common factors in cloud services pricing is critical. In this paper will be shown various pricing model for cloud computing, and how they affect in different resources, their comparison, also the pricing model for two platforms: 1) Google Cloud Computing; and 2) Amazon Web Services.
\end{abstract}

Keywords-Component; Cloud Computing pricing model; comparison of pricing model; Google Cloud platform and Amazon Web Service pricing model

\section{INTRODUCTION}

This paper shows the importance of various prices models that the Cloud technology use, and it's use in many situations. Nowadays, Cloud Computing has become an essential part of the digital world. A Cloud is a sample of similar and distributed system that has an accumulation of inter-connected and virtually computers, which presents as one or more unified computing resources based on a convention between the service provider and consumers [1].

The use of Cloud Computing and the services offered by many company is increasing a lot every day. Today, we might see that needs and demands are increasing for these kinds of things, that allow us to have our space without having the need to secure hardware for storage or for various services, which will give a cost of thousands to have under our proprietary. However, a massive use of these services and multiple offers showed from different cloud platforms, provides various services as for compute, storage, big data, analytics, database, etc. often create confusion for the prices to the consumers. How many affects have prices in the use of these services? What are the kinds of pricing model that Amazon Web Services and Google Cloud Platform have?

Computing is a sample consisting of services that are similar to traditional benefits such as water, power, etc. In this model, users access services without having a need to connect with the main services. So, the principal part of it is Cloud computing [2].
Cloud computing is suitable for business owners because it gives the users to plan for their provision and allows enterprises to raise their resources only when there is an expansion in service demand [3]. The main part of it is that users don't have to know all the things about it or to have great ability to use them [2].

We can say that cloud providers form an oligopoly, with their equilibrium prices is like a Cournot equilibrium, which gives prices above the competitive price (is the time when prices equal production costs), but when it comes to decreasing resource costs, it changes a lot [4]. Even though Cloud service plays a key role in the success of cloud computing, exciting pricing models cannot respond quickly to market changes [5].

Pricing model in Cloud Computing is inclinable than other models, having its pricing scheme. Cloud Computing focuses to accomplish and to assure the quality of service (QoS) for clients [6].

The rest of the paper is organized as: Section 2 presents Overview of Cloud Computing. Section 3 describes Cloud Computing Pricing model. Section 4 shows Comparison of the Cloud Computing Pricing model and pricing model for cloud platforms: Amazon Web Service and Google Cloud. Section 5 has the Conclusion and the last section presents References used in the paper.

\section{OVERVIEW OF CLOUd COMPUTING}

Cloud computing is a significant model for computing recourses, for instance, networks, storage, application, and services. As a service, it provides some facilities, like a cheap cost of services, high performances, scalability [7].

For many years cloud computing has become a lower cost for corporate computing market, as software, hardware, processing power, and storage capacity become more commoditized [8].

Using it gives a way to share computing resources that include applications, computing, storage, networking, development and deployment platforms which users can use it at any time [9].

Paradigms of Cloud Computing are being discussed based on the technical, business, and human factors, analyzing how business and technology strategy is being influenced by the following aspects of cloud computing: Architecture, Security, Costs, Hardware/software trends, Organizational/Human Factors [10]. 

[11]:

Essential characteristics of cloud computing platforms are

1) The provider will take care of fluctuation demand (Dynamism).

2) Everything (OS, the plug-ins, web security or the software platform) should be in place without any worry of end-user (Abstraction).

3) A company dealing with Payroll Management may require more resources at the end or beginning of the month (Resource Sharing).

4) Pay-as-you-go ensures users that will never pay anything extra. Users will have the possibility to save money.

There were a lot of websites that started with cloud computing, for instance, the first one was in 1999 called Salesforce.com, which provided an application for delivering enterprise using the website. On the other hand, the second one who introduced Amazon Web Service in 2002 was the Amazon, after that Google Docs in 2006 was another factor to take the attention of public for cloud computing. In 2006, Amazon's Elastic Compute Cloud (EC2) gave the opportunity to companies and individuals to rent computers on which they could run their computer applications. Eucalyptus in 2008 with the source called AWS API created private clouds, followed by Open Nebula which was the first open source software for distributing private and hybrid clouds. In November 2009, Windows Azure from Microsoft entered with cloud computing. Today, you may see a major number of sources who use cloud computing [12], [13].

Using cloud computing helps to raise their profits with minimal output, and this is not just a distribution among different businesses; it is also the one that offers the best service to its clients [14].

Cloud Services provides many platform; in this case, would be taken to compare prices models for:

1) Google Cloud Platform: This platform provides to the people their chance to build, test, and deploy an application using reliable infrastructure. This platform can take from computing, storage, and application services for the web, mobile and backend solutions [15]. Google Cloud Platform provides services for Compute, Storage \& Database, Networking, Big Data, Internet of Thing, Machine Learning, Identity \& Security, Management Tools, and Development Tools [16].

2) Amazon Web services: Amazon Web Services (AWS) is a secure cloud services platform, offering computing power, database storage, content delivery and other functionality to help businesses scale and grow [17]. AWS has been operating since 2006, and from that time it had spent millions of dollars building and managing the large-scale, reliable, and efficient IT infrastructure that powered one of the world's largest online retail platforms. Nowadays the Amazon serves hundreds of thousands of customers worldwide, can say that it had arrived at its goal [18]. Amazon provides services for Compute, Storage, Database, Networking \& Content Delivery, Developer Tools, Management Tools, Analytics, Security, Identity \& Compliance, Mobile Services, Application Services, Messaging, Business Productivity, Desktop \& App Streaming, Software, Migration, Artificial Intelligence, Contact Center, Game Development, and Internet of Things [19].

The principal part of Cloud Computing is Cloud Platform, in that part developers write applications that run in the cloud or they just can use services offered by the cloud, or both of them [20]. Amazon and Google are the first that offer cloud computing platforms. They have invested a lot for delivering scalable compute, storage and database services. Both provide web services accessed through simple API endpoints that can take infrastructure, store data, or create a network [21].

The aim of this paper is to offer descriptions and information about prices models for cloud computing and to show few differences between them, to help potential customers to know more about it.

\section{Cloud Computing Pricing Model}

The price presents an essential element, an indicator that often shows the quality of services, but on other side also setting prices from the salesman has an impact directly on clients' decisions to use them. For both providers and users of cloud services, identifying the common factors in cloud services pricing is critical.

We all know that in the market, customers should have the ability to compare their options and choose the best, while providers will have to show their pricing models to standard their schemes, in order to raise their quality of services [22].

A cloud computing provider's typical goal is to maximize its revenues with its employed pricing scheme, while for customers is to obtain the highest level of quality of service (QoS) feasible for a reasonable price. Therefore, satisfying both parties requires an optimal pricing methodology [23].

Anyway, the pricing model is a relationship between providers and customers, for which they should agree with it. Providers have their accounting system to calculate the price for the cloud services. All of them try to make benefit from it, while customers try to have the maximum service for lower prices. So, the price is an important element for the company, because this has an effect directly to the consumer and organization profit [6]. We could say that pricing is the key of what a service provider will accept from an end user instead of their services [23].

Fig. 1 presents a model for cloud computing cost accounting which addresses cost accounting issues in the production of cloud services. Services provider has infrastructure cloud, which allows them building platforms and services on top of it [24]. 


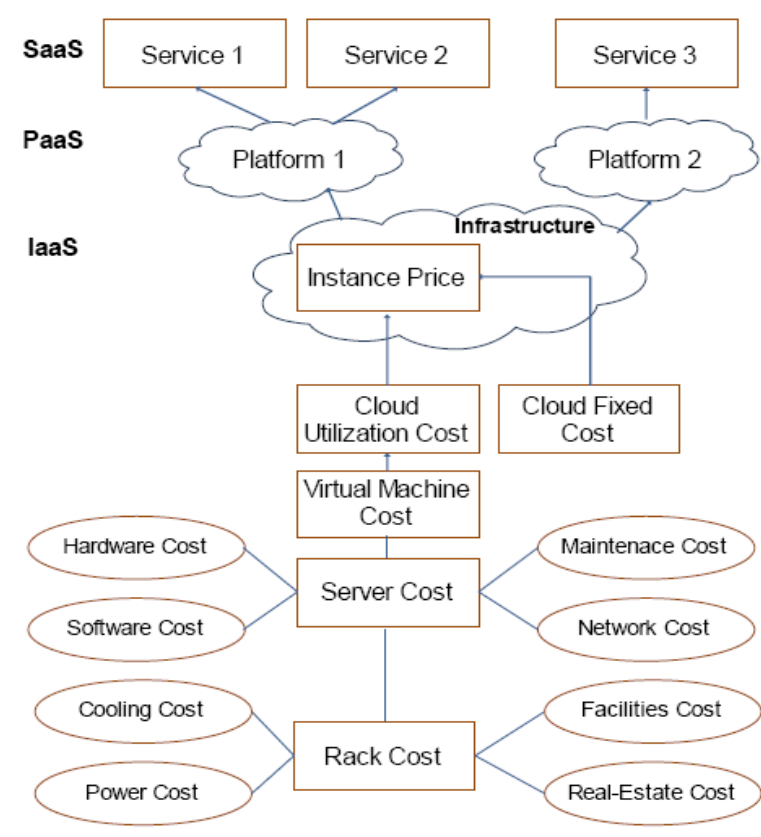

Fig. 1. Cloud computing cost accounting model.

Pricing in Cloud Computing has two impact aspects. First, pricing has its root in system design and optimization, resource-consumption based pricing is particularly sensitive to how a system is designed, configured, optimized, monitored, and measured. Second, pricing also has its root in economics, where key concepts such as fairness and competitive pricing in a multi-provider marketplace affect the actual pricing [25].

Cloud computing is a substantial practice for the online provisioning of computing resources as services. This technology allows sharing of resources and costs among a large number of end users. It provides end users to process, manage, and store data efficiently at very high speeds. Clients don't have to install any software and can access their data from any computer till the internet connection is available [23]. The interaction between systems and economy on price model has an important implication on cloud computing that should be explored by researchers [25].

The definitions and a short description of pricing schemes which varies depending on the services are shown below [6]:

1) Time-based: Pricing based on how long a service is being used.

2) Volume based: Pricing based on the capacity of a metric.

3) Flat rate: A fixed tariff for a specified amount of time.

4) Priority pricing: Services are labeled and priced according to their priority.

5) Edge pricing: A calculation is done based on the distance between the service and the user.

6) Responsive pricing: Charging is activated only on service congestion.

7) Session-oriented: Based on the use given to the session.

8) Usage-based: Based on the general use of the service for a period, e.g. a month.

9) Content-based: Based on the accessed content.

10)Location-based: Based on the access point of the user.
11)Service type: Based on the usage of the service.

12)Free of charge: No charge for the services.

13)Periodical fees: Payment of time to time quantities for the use of a service.

14)Pre-paid: The payment for the service will be in advance.

15)Post-paid: The payment for the service will be after it's use.

16) Online: The accounting performed while the user makes use of a service.

17)Offline: After the use of the service, the accounting process should proceed.

Price also is considered a key element in economic term with many factors which affect it [25]. The influencing factors for pricing in cloud computing [6], [23]:

1) Initial costs: This is the amount of money that the service provider spends annually to buy resources.

2) Lease period/contract time: This is the period in which the customer will lease resources from the service provider. Service providers usually offer lower unit prices for longer subscription periods.

3) QoS: This is the set of technologies and techniques provided by the service provider to enhance the user experience in the cloud, such as data privacy and resource availability. The better QoS offered, the higher the price will be.

4) Age of resources: This is the age employed by the service provider. The fee will be lower if the recourse is older than the others and this is because it can maintain their consumption which facilitates their financial value.

5) The cost of maintenance: This is the amount of money that the service provider spends on maintaining and securing the cloud annually.

6) The rate of depreciation: This is the rate at which the hardware of service provider is expected to lose its financial value.

Consumers have to be sure that the service they are paying for has to be delivered to them unbreakable. They can use SLAs (Service Level Agreements) between the consumers and providers to do it. An efficient economic model is being a challenge for enterprise working in the field of cloud computing [26].

Two pricing schemes for cloud are [27]:

1) Static pricing (fixed): This repair all prices for the whole time horizon. The cloud computing services are highly time dependent, so the time interval of offered service is predetermined.

\section{2) Dynamic pricing.}

These are two important criteria to decide the cost of query: availability when a user demands something from the cloud, a query is fired to the cloud and time horizon, i.e., when request a query.

The difference between fixed and dynamic is that in fixed pricing, each resource type has a predefined price, set by the 
seller, while using dynamic pricing, computes each request according to the pricing mechanism used [28].

Fixed pricing mechanisms sets prices that do not differentiate in function of customer characteristics are not volume dependent and are not based on real-time market conditions. The mechanisms used are pay-per-use, subscription and menu pricing. In pay-per-use, the customer pays in function of the time or quantity he consumes for a product or service. For example, if they listen an online music he could be charged, or online newspaper may charge him for every article read. When he uses a subscription, the customer pays a flat fee for using a product or to profit from a service [29].

Fixed prices were easier to understand and more straightforward for users. Anyway, they could not be fair to all users [23]. Also, supports assurances for consumers, lets consumers know how much they will pay, is more consistent, reduces risks, makes profit estimation easy. However, disadvantages of fixed pricing model is that sometimes it is unfair for consumer because if the user doesn't consume the resource extensively, he/she may pay more than his/her real utilization. Moreover, it doesn't allow provider to change price for any account, unfair for them, it could happen that consumer may pay less than his/her real utilization [30]. Consumers also might be charged for resources they have not consumed. Their usage stops if they reach the maximal limit [22].

Dynamic price is based on pricing mechanism whenever there is a request. Sometimes the price of the resources is determined according to demand and supply [6]. Using dynamic pricing a firm delays its pricing decisions until after discoveres the market condition, so that it can fit prices accordingly, when demand is ample, set a high price, and when demand is weak, set a low price. But, many firms do not adjust prices to respond to market conditions [31]. Dynamic pricing is the monopolist that sells a single product and have perfect information about the demand distribution [22].

This model supports sellers to maximize profits with each consumer, fair for a consumer as it allows him to pay according to the offered QoS, and they could set the price according to a current state of the market. However, this model has also disadvantages such as consumers are not interested in this model, the one that pays more feel inequality, creating him negative opinions for dynamic pricing [30].

We have many business models based on different service models that define the price of services in the cloud [6].

\section{A. Pricing model}

Pricing is the process of determining what a service provider will receive from an end user in exchange for their services [23]. The service gives a price for resources that go to the costumer, reducing customer base and decreasing in revenue and profits [6].

Prices that are being used increasingly are pay-per-use and subscription [23], [32].

If customer use pay-per-use then he/she will pay only for what he/she is using, for a period of a particular service, it helps them to do business and consume the resource [6]. In pay-per-use model, the customers pay for the amount they consume of a product or the amount of time they use for a certain service [23]. It is the most used model, in which the consumer is charged a fee for a used unit for a specified duration. The unit used may be a certain computing unit of hardware, software or application, for example, GB or CPU [33]. Pay-per-use is called a piece of cloud concept heart [34].

Fixed-price model, sometimes called subscription, charges the user for using a service unit for a fixed price, usually in period of month or year [33]. Subscription is used from user paying just for accessing the software as an online service [6]. It is one of the pricing models, and customer subscribes it with a particular service provider for a fixed price [23]. The consumer has to sign a contract with all the criteria for using the service unit [35].

When we consider these two techniques: subscription and pay-per-use, we would say that subscription is more likely to be used in a time when customers don't like the time to complete the service, giving the firm a lot of costs. So, they should invest or cover that large capacity cost only when they get enough revenue from customers. However, pay-per-use generates higher revenue if revenue is reasonably low, while subscription pricing is considerable [36].

\section{COMPARISON OF Cloud COMPUTING PRICING MOdEL}

Based on data obtained from the various publication of prices scheme (static or fixed and dynamic) in Cloud Computing shown in Section 3, will be presented with differences, and advantages and disadvantages of them.

The following table presents the differences between fixed and dynamic pricing:

TABLE. I. DIFFERENCES BETWEEN FIXED AND DYNAMIC PRICING

\begin{tabular}{|l|cc|}
\hline & $\begin{array}{l}\text { Differences between Fixed and Dynamic } \\
\text { Pricing }\end{array}$ \\
\hline Fixed pricing & $\begin{array}{l}\text { The resource has a predetermined price, } \\
\text { set by provider }\end{array}$ \\
& $\begin{array}{c}\text { Could not be fair to all } \\
\text { consumer }\end{array}$ \\
\hline Dynamic pricing & $\begin{array}{l}\text { The resource will be count for each request } \\
\text { based on pricing mechanism used. }\end{array}$ \\
\hline
\end{tabular}

In Table 1, the main difference between this two pricing scheme has been presented, which shows the way how they make prices for a resource or a particular service differs from other. In fixed pricing, the resource has a predetermined price, given by provider, while dynamic, calculate pricing for each request based on the mechanism used. Using static pricing, the customer cannot change the price after its determination, while in dynamic pricing, the price will change depending on their demand. Then, another difference between them is the way how they treat their customer, fixed pricing could not be fair, while in dynamic pricing, it is.

The following table presents the advantages of fixed and dynamic pricing: 
TABLE. II. ADVANTAGES OF FIXED AND DYNAMIC PRICING

\begin{tabular}{|l|l|l|}
\hline & Fixed pricing & Dynamic pricing \\
\hline \multirow{4}{*}{} & $\begin{array}{l}\text { Better to enforce on consumers } \\
\text { rationing risk }\end{array}$ & $\begin{array}{l}\text { Firm delays its pricing } \\
\text { decisions until after market } \\
\text { recealed its conditions }\end{array}$ \\
\cline { 2 - 3 } & $\begin{array}{l}\text { Easier to understand and more } \\
\text { forthright for users }\end{array}$ & Fair for consumers \\
\cline { 2 - 3 } & $\begin{array}{l}\text { Supports securities, more } \\
\text { stable, reduce risks }\end{array}$ & $\begin{array}{l}\text { Supports provider to } \\
\text { maximize profits with each } \\
\text { consumer }\end{array}$ \\
\cline { 2 - 4 } & Makes profit estimation easy & $\begin{array}{l}\text { Setting price based on the } \\
\text { current state of the market. }\end{array}$ \\
\hline
\end{tabular}

Both, fixed and dynamic pricing have their advantages that characterize them in their use. For instance, while fixed price is more forthright for the user, dynamic pricing is fair for it; while static pricing supports securities, dynamic pricing supports provider to maximize profits with each consumer.

The following table shows the disadvantages of fixed and dynamic pricing:

TABLE. III. DisAdVANTAges OF PRICING SchEME

\begin{tabular}{|c|c|c|}
\hline & Fixed pricing & Dynamic pricing \\
\hline \multirow{7}{*}{ 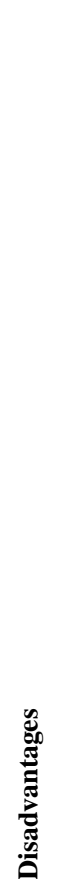 } & $\begin{array}{l}\text { Produce prices that do not } \\
\text { vary in function of customer }\end{array}$ & $\begin{array}{l}\text { Enforces a price risk on } \\
\text { consumers }\end{array}$ \\
\hline & $\begin{array}{l}\text { Are not based on real-time } \\
\text { market conditions }\end{array}$ & $\begin{array}{l}\text { Consumer might pay higher } \\
\text { price than can pay }\end{array}$ \\
\hline & Could not be fair to all users & $\begin{array}{l}\text { Many firms don't suit prices } \\
\text { to respond to market } \\
\text { conditions }\end{array}$ \\
\hline & $\begin{array}{l}\text { Doesn't allow provider to } \\
\text { change price for any reason }\end{array}$ & $\begin{array}{l}\text { Many users are not } \\
\text { interested in this model }\end{array}$ \\
\hline & $\begin{array}{l}\text { Unfair for provider } \\
\text { (consumer may pay less than } \\
\text { his/her real utilization) }\end{array}$ & $\begin{array}{l}\text { Consumer who pay more } \\
\text { feel inequality }\end{array}$ \\
\hline & $\begin{array}{l}\text { Consumers might be charged } \\
\text { for resources they have not } \\
\text { consumed }\end{array}$ & \\
\hline & $\begin{array}{l}\text { Could be stopped if } \\
\text { consumers reach the maximal } \\
\text { limit }\end{array}$ & \\
\hline
\end{tabular}

Besides the advantages shown in Table 2, fixed and dynamic pricing also have their disadvantages. Table 3 shows some of the disadvantages of these pricing schemes. For example, one for fixed pricing is that it charges it's consumer for resources they have not consumed, while in dynamic pricing they might pay more than they can pay.
The table below, shows the comparison of some pricing model. All pricing models presented belongs to the pricing scheme: static and dynamic.

Table 4 presents some pricing model for cloud computing, for which the description is for each of them, the way how they treat customers, advantages and disadvantages and their implementation. From the model shown in the table, many of them are as the theoretical study with simulation.

\section{B. Google Cloud Platform vs. Amazon Web Services: Pricing Model}

Amazon Cloud Platform and Google platform offer a lot of cloud services, and both of them have their way how the users have to pay services that they offer: "Pay-as-you-go" for Amazon and "pay only for what you use" for Google [37], [38].

The challenge for service providers is to provide better services for a reasonable price to users. The pricing should be on customer's perceived value instead of production costs of services [6].

Amazon Web Services (AWS) provides a pay-as-you-go approach paying it only for a particular service you need, without having any problem with contracts or complex licensing. It is the same how people use water or electricity, paying just for the period that you use it and has not an additional cost or termination fees [37].

Below you may find the way how two platforms offer their product and how they set the price. While both of them have services for a virtual machine, they indeed have differences between each other.

For Google Compute Engine product, Google platform offers two categories of machine types: predefined machine types, which have preset virtualized hardware properties and a set price; and custom machine types where they take the price according to the number of vCPUs and memory that the virtual machine instance uses.

Below are presented billing model which applies to all types, predefined or custom [43]:

1) Charging all types for a minimum of $\mathbf{1 0}$ minutes. For example, if you run your virtual machine for 2 minutes, you will be billed for 10 minutes of usage.

2) After 10 minutes, instances are charged in 1-minute increments, rounded up to the nearest minute. An instance that lives for 11.25 minutes charges for 12 minutes of usage.

Amazon EC2 (Amazon Elastic Compute Cloud) provides to the consumers a model pay only for you, where they calculate pricing per instance-hour consumed, so each partial instance-hour consumed will be billed as a full hour. This service offers instance in four ways of paying [44]:

1) On-demand instance.

2) Reserved instance.

3) Spot instance.

4) Dedicated hosts. 
TABLE. IV. COMPARISON OF PRICING MODEL

\begin{tabular}{|c|c|c|c|c|}
\hline Pricing model & $\begin{array}{l}\text { Operation } \\
\text { (description) }\end{array}$ & Features and Fairness & $\begin{array}{l}\text { Advantages (A) } \\
\text { Disadvantages (D) }\end{array}$ & Implementation \\
\hline Pay-as-you-go [6] & $\begin{array}{l}\text { Price is set by a service } \\
\text { provider and remains } \\
\text { constant. This model is } \\
\text { static }\end{array}$ & $\begin{array}{l}\text { Unfair to the client. He might pay } \\
\text { more than necessary }\end{array}$ & $\begin{array}{l}\text { (A) - Resources/Services are } \\
\text { available during reservation period, and } \\
\text { the price is known } \\
\text { (D) - Over-provisioning and } \\
\text { Under-provisioning' problems may occur. } \\
\text { The price is unchangeable [29] }\end{array}$ & Implemented [37] \\
\hline Subscription [30] & $\begin{array}{l}\text { Price is based on the } \\
\text { period of subscription }\end{array}$ & $\begin{array}{l}\text { Sometimes consumer might pay } \\
\text { more for a resource }\end{array}$ & $\begin{array}{l}\text { (A) - It is good for consumer } \\
\text { When utilize extensively } \\
\text { Resources/Services } \\
\text { (D) - Consumer may pay more than the } \\
\text { real utilization cost when he/she does not } \\
\text { use } \\
\text { Resources/Services properly }\end{array}$ & Implemented [38] \\
\hline $\begin{array}{l}\text { Dynamic resource } \\
\text { pricing }[28]\end{array}$ & $\begin{array}{l}\text { It is a dynamic pricing } \\
\text { model used for } \\
\text { federated cloud and } \\
\text { facilitates sellers to } \\
\text { provide multiple } \\
\text { resource types. }\end{array}$ & $\begin{array}{l}\text { Resource payments are assigned } \\
\text { based on demand and supply. }\end{array}$ & $\begin{array}{l}\text { (A) - It can balance the number of } \\
\text { successful requests and the number of } \\
\text { allocated resources depending on the } \\
\text { market condition [28]. } \\
\text { (D) - Less scalability of high demand in } \\
\text { the market than fixed pricing }\end{array}$ & $\begin{array}{l}\text { Theoretical study } \\
\text { With simulation }\end{array}$ \\
\hline Pay-for-recourses & $\begin{array}{l}\text { It is a static model } \\
\text { which will set by cloud } \\
\text { provider }\end{array}$ & $\begin{array}{l}\text { Fair for both customers and the } \\
\text { service provider }\end{array}$ & $\begin{array}{l}\text { (A)- Offers maximum utilization of the } \\
\text { service provider's resources } \\
\text { (D) }\end{array}$ & Implemented [38] \\
\hline $\begin{array}{l}\text { Hybrid pricing } \\
{[23]}\end{array}$ & $\begin{array}{l}\text { Price changed according } \\
\text { to the job queue wait } \\
\text { times (static/dynamic) }\end{array}$ & $\begin{array}{l}\text { Fair to customers because of the } \\
\text { price authority entity, which } \\
\text { dynamically adjusts prices within } \\
\text { static limits }\end{array}$ & $\begin{array}{l}\text { (A) - Simple and has lower computational } \\
\text { overhead } \\
\text { (D) - Must reach an agreement on } \\
\text { common base price and variation limits }\end{array}$ & Implemented \\
\hline $\begin{array}{l}\text { Dynamic auction } \\
{[35]}\end{array}$ & $\begin{array}{l}\text { This mechanism used } \\
\text { the approach of pricing, } \\
\text { truthfulness and } \\
\text { dynamic adjustment } \\
\text { mechanisms }\end{array}$ & $\begin{array}{l}\text { Dynamic adjustments } \\
\text { tolerate fluctuation of users' } \\
\text { distributions. }\end{array}$ & $\begin{array}{l}\text { (A) - Dynamic adjustments } \\
\text { tolerate fluctuation of users' } \\
\text { distributions. }\end{array}$ & $\begin{array}{l}\text { Theoretical study } \\
\text { with simulation }\end{array}$ \\
\hline $\begin{array}{l}\text { A novel financial, } \\
\text { economic model } \\
\text { [39] }\end{array}$ & $\begin{array}{l}\text { This model is dynamic, } \\
\text { usage-based. }\end{array}$ & $\begin{array}{l}\text { It is fair for service provider and } \\
\text { consumer. }\end{array}$ & $\begin{array}{l}\text { (A) - It provides a high level of Quality of } \\
\text { Service for clients. } \\
\text { (D) - Does not consider maintenance costs } \\
\text { and assumes the price charged for assets } \\
\text { for customers }\end{array}$ & $\begin{array}{r}\text { Theoretical study } \\
\text { with simulation }\end{array}$ \\
\hline $\begin{array}{l}\text { Pricing algorithm } \\
\text { for cloud } \\
\text { computing [23] }\end{array}$ & $\begin{array}{l}\text { It is a real time pricing } \\
\text { This model is dynamic }\end{array}$ & $\begin{array}{l}\text { Fair for provider because it } \\
\text { reduces costs and maximizes } \\
\text { revenues }\end{array}$ & $\begin{array}{l}\text { (A) - Reduces the costs of the providers; } \\
\text { maximizes revenues } \\
\text { (D) - Model is almost fixed and cannot } \\
\text { adapt to rapid changes in supply and } \\
\text { demand in the market }\end{array}$ & $\begin{array}{l}\text { Theoretical study } \\
\text { with simulation }\end{array}$ \\
\hline $\begin{array}{l}\text { Costumer-based } \\
\text { pricing }[6,40]\end{array}$ & $\begin{array}{l}\text { In this dynamic price is } \\
\text { set according to } \\
\text { consumer requirements } \\
\text { and needs }\end{array}$ & $\begin{array}{l}\text { This model is fair for clients if it } \\
\text { is taken into account }\end{array}$ & $\begin{array}{l}\text { (A) - Considerate Cloud Computing } \\
\text { (D) - vendors try to charge prices lower } \\
\text { than their competitors. }\end{array}$ & Implemented \\
\hline $\begin{array}{l}\text { Cost-based } \\
\text { pricing }[6,41]\end{array}$ & $\begin{array}{l}\text { In this model, the } \\
\text { priority is to increase } \\
\text { the profit. }\end{array}$ & This model is not fair to consumer & $\begin{array}{l}\text { (A) Easy to calculate the price } \\
\text { (D) - Determining the price by the } \\
\text { provider without the customer's influence. }\end{array}$ & Implemented \\
\hline $\begin{array}{l}\text { Double sided } \\
\text { combinational } \\
\text { auction to } \\
\text { resource } \\
\text { allocation }[11,42]\end{array}$ & $\begin{array}{l}\text { This model is for } \\
\text { service allocation that } \\
\text { enables users and } \\
\text { providers to deal } \\
\text { through double-sided } \\
\text { combinational auction. }\end{array}$ & $\begin{array}{l}\text { Users and service providers } \\
\text { should be satisfied by the resource } \\
\text { allocation mechanism }\end{array}$ & $\begin{array}{l}\text { (A) - suitable for cases requiring various } \\
\text { services and where many participants exist } \\
\text { (D) - doesn't make optimization of energy } \\
\text { consumption }\end{array}$ & $\begin{array}{l}\text { Theoretical study } \\
\text { with simulation }\end{array}$ \\
\hline $\begin{array}{l}\text { Value-based } \\
\text { pricing [30] }\end{array}$ & $\begin{array}{l}\text { This model is dynamic. } \\
\text { Service prices are } \\
\text { defined depending on } \\
\text { the customer's point of } \\
\text { view }\end{array}$ & It is fair to consumer & $\begin{array}{l}\text { (A) - Increases revenues } \\
\text { (D) - Hard to implement }\end{array}$ & Implemented \\
\hline
\end{tabular}




\begin{tabular}{|l|l|l|l|l|}
\hline $\begin{array}{l}\text { Genetic model for } \\
\text { pricing in cloud } \\
\text { computing } \\
\text { markets [23] }\end{array}$ & $\begin{array}{l}\text { It is real-time based } \\
\text { pricing. This model is } \\
\text { dynamic }\end{array}$ & $\begin{array}{l}\text { Biased toward the service } \\
\text { provider; the algorithm considers } \\
\text { increasing revenues }\end{array}$ & $\begin{array}{l}\text { (A) - Achieves very high revenues, Stable } \\
\text { against noises, Flexible, Easy to } \\
\text { implement } \\
\text { (D) - Assumes that the market behaves } \\
\text { rationally, which might cause the model to } \\
\text { underperform in very high and very low } \\
\text { demand conditions }\end{array}$ & $\begin{array}{l}\text { Theoretical study } \\
\text { with simulation }\end{array}$ \\
\hline $\begin{array}{l}\text { Competition- } \\
\text { based pricing [28, } \\
\mathbf{4 0 ]}\end{array}$ & $\begin{array}{l}\text { In this model price } \\
\text { assigned according to } \\
\text { competitors' prices. } \\
\text { This model is dynamic. }\end{array}$ & $\begin{array}{l}\text { A fair model because the price } \\
\text { assigned according to } \\
\text { competitors' prices. }\end{array}$ & $\begin{array}{l}\text { (A) - Easy to implement } \\
\text { (D) - Ignores the cloud customers }\end{array}$ & Implemented \\
\hline $\begin{array}{l}\text { Datacenter net } \\
\text { profit } \\
\text { optimization } \\
\text { with } \\
\text { individual job } \\
\text { deadlines [23] }\end{array}$ & $\begin{array}{l}\text { This is a job scheduling } \\
\text { based model. This } \\
\text { model is dynamic. }\end{array}$ & $\begin{array}{l}\text { Biased toward the service } \\
\text { provider; it mainly reduces costs } \\
\text { and increases }\end{array}$ & $\begin{array}{l}\text { (A) - Maximizes revenues for the service } \\
\text { provider and minimizes electricity } \\
\text { (D) - Considers only static job arrivals and } \\
\text { departures and assumes }\end{array}$ & $\begin{array}{l}\text { Theoretical study } \\
\text { with simulation }\end{array}$ \\
\hline
\end{tabular}

\section{CONCLUSION}

This paper presents Cloud Computing and its pricing model. Firstly, describes two main schemes for pricing: fixed and dynamica, then in Section 4 a comparison between how they set the price and their advantages and disadvantages. Then, in Section 3, two pricing models: pay-per-use and subscription are presented which are the most used models.

Aside from in Section 4, you might find the comparison of some of the pricing models and their characteristics, where you can find their description, fairness, advantages and disadvantages, and their implementation.

In the end, shows two platforms: Amazon and Google cloud, where there is also presented the main pricing model with an example of how their platform set the price for a particular product.

\section{REFERENCES}

[1] Buyya, Rajkumar, et al. "Cloud computing and emerging IT platforms: Vision, hype, and reality for delivering computing as the 5th utility." Future Generation Computer systems 25.6 (2009): 599-616.

[2] IEEE UCC,"The 5th IEEE/ACM International Conference on Utility and Cloud Computing” IEEE UCC 2012, Chicago, Illinois, US, available at http://cloudcomputing.ieee.org/conferences/calendar/view/144/23.\%202 $\underline{012}$

[3] Zhang, Qi, Lu Cheng, and Raouf Boutaba. "Cloud computing: state-ofthe-art and research challenges." Journal of Internet services and applications 1.1 (2010): 7-18.

[4] Kash, Ian A., and Peter B. Key. "Pricing the Cloud." IEEE Internet Computing 20.1 (2016): 36-43.

[5] Wang, Wei, Ben Liang, and Baochun Li. "Revenue maximization with dynamic auctions in IaaS cloud markets." The quality of Service (IWQoS), 2013 IEEE/ACM 21st International Symposium on. IEEE, 2013.

[6] Mazrekaj, Artan, Isak Shabani, and Besmir Sejdiu. "Pricing Schemes in Cloud Computing: An Overview." INTERNATIONAL JOURNAL OF ADVANCED COMPUTER SCIENCE AND APPLICATIONS 7.2 (2016): 80-86.

[7] Mell, Peter, and Tim Grance. "The NIST definition of cloud computing." (2011)..

[8] Wyld, David C. "The utility of cloud computing as a new pricing-and consumption-model for information technology." International Journal of Database Management Systems 1.1 (2009): 1-20.

[9] Judith Hurwitz, Marcia Kaufman, Fern Halper: Cloud Services for Dummies -IBM Limited Edition, John Wiley \& Sons, Inc, New Jersey, 2012
[10] Gorelik, Eugene. Cloud computing models. Diss. Massachusetts Institute of Technology, 2013.

[11] Basant Narayan, Cloud Computing for Beginners, Techno-Pulse, 2010

[12] Dikaiakos, Marios D., et al. "Cloud computing: Distributed Internet computing for IT and scientific research." IEEE Internet Computing 13.5 (2009): 10-13.

[13] Ivan Zapevalov, "The Basics of Cloud Computing" Conseil Européen pour la Recherche Nucléaire, pp. 7, Geneva, Switzerland, available at http://ais-grid-2013.jinr.ru/docs/24/1-CloudComputing_IZ.pdf. 2013

[14] Aljabre, Abdulaziz. "Cloud computing for increased business value."International Journal of Business and Social Science 3.1 (2012).

[15] Google Cloud Platform, “Why Google,” https://cloud.google.com/whygoogle/

[16] Google Cloud Platform, "Products," available at https://cloud.google.com/products/

[17] Amazon Web Services, available at http://aws.amazon.com/what-is-aws/

[18] Mathew, Sajee. "Overview of Amazon Web Services." Amazon Whitepapers(2014).

[19] Cloud products \& services - Amazon Web Service available at https://aws.amazon.com/products/

[20] Chappell, David. "A short introduction to cloud platforms." David Chappell \& Associates (2008).

[21] Google cloud vs. Amazon, https://cloud.google.com/docs/compare/aws/, last accessed 18.08.2016

[22] Bitran, Gabriel, and René Caldentey. "An overview of pricing models for revenue management." Manufacturing \& Service Operations Management5.3 (2003): 203-229.

[23] Al-Roomi, May, et al. "Cloud computing pricing models: a survey."International Journal of Grid \& Distributed Computing 6.5 (2013): 93-106.

[24] Jäätmaa, Jaakko. "Financial aspects of cloud computing business models." (2010).

[25] Wang, Hongyi, et al. "Distributed Systems Meet Economics: Pricing in the Cloud." HotCloud 10 (2010): 1-6.

[26] Chawla, Chetan, and Inderveer Chana. "Day-ahead Pricing Model for Smart Cloud using Time-Dependent Pricing." International Journal of Computer Network and Information Security 7.11 (2015): 9.

[27] Kamra, Varun, Kapil Sonawane, and Pankaja Alappanavar. "Cloud computing and its pricing schemes." International Journal of Computer Science and Engineering 4.4 (2012): 577.

[28] Mihailescu, Marian, and Yong Meng Teo. "Dynamic resource pricing on federated clouds." In Proceedings of the 2010 10th IEEE/ACM International Conference on Cluster, Cloud and Grid Computing. IEEE Computer Society, 2010.

[29] Osterwalder, Alexander. "The business model ontology: A proposition in a design science approach." (2004).

[30] Ali, Taj-Eldin Suliman M., and Hany H. Ammar. "Pricing Models for Cloud Computing Services, a Survey." 
[31] Cachon, Gérard P., and Pnina Feldman. "Dynamic versus static pricing in the presence of strategic consumers." Retrieved April 15 (2010): 2011.

[32] Weinhardt, Christof, et al. "Cloud computing-a classification, business models, and research directions." Business \& Information Systems Engineering 1.5 (2009): 391-399.

[33] Weintraub, Eli, and Yuval Cohen. "Cost Optimization of Cloud Computing Services in a Networked Environment." International Journal of Advanced Computer Science and Applications 6.4 (2015): 148-157.

[34] Weinman, Joe. "The Economics of Networking and the Cloud." IEEE Cloud Computing 3.3 (2016): 12-15.

[35] Samimi, Parnia, and Ahmed Patel. "Review of pricing models for grid \& cloud computing." Computers \& Informatics (ISCI), 2011 IEEE Symposium on. IEEE, 2011.

[36] Cachon, Gérard P., and Pnina Feldman. "Pricing services subject to congestion: Charge per-use fees or sell subscriptions?." Manufacturing \& Service Operations Management 13.2 (2011): 244-260.

[37] AWS Pricing, https://aws.amazon.com/pricing/, last accessed 19.08.2016
[38] Pricing, Cloud Pub/Sub Documentation, Google Cloud Platform, https://cloud.google.com/pubsub/pricing, last accessed 20.08.2016

[39] Sharma, Bhanu, et al. "Pricing cloud compute commodities: a novel financial economic model." Proceedings of the 2012 12th IEEE/ACM international symposium on cluster, cloud and grid computing (CCGrid 2012). IEEE Computer Society, 2012.

[40] Rohitratana, Juthasit, and Jörn Altmann. "Agent-based simulations of the software market under different pricing schemes for software-as-aservice and perpetual software." International Workshop on Grid Economics and Business Models. Springer Berlin Heidelberg, 2010.

[41] Lehmann, Dipl-Wirtsch-Ing Sonja, and Peter Buxmann. "Pricing strategies of software vendors." Business \& Information Systems Engineering 1.6 (2009): 452-462.

[42] Fujiwara, Ikki, Kento Aida, and Isao Ono. "Applying double-sided combinational auctions to resource allocation in cloud computing."Applications and the Internet (SAINT), 2010 10th IEEE/IPSJ International Symposium on. IEEE, 2010.

[43] Google compute engine, https://cloud.google.com/compute/pricing, last accessed 25.05.2017

[44] Amazon EC2 Pricing, https://aws.amazon.com/ec2/pricing/, last accessed 25.05.2017 